\title{
Freelance Market Development Factors
}

\author{
Diana Zh.Abdreissova ${ }^{1 *}$, Daniyar T. Baitenizov ${ }^{1}$, Tolkyn A. Azatbek ${ }^{2}$, Saltanat N.Valieva \\ ${ }^{\prime}$ M.Kozybaev North Kazakhstan University, 86 Pushkin Str., 150000, Petropavlovsk, Kazakhstan \\ ${ }^{2}$ L.N. Gumilyov Eurasian National University, 2 Satpayev Str., 010000, Nur-Sultan, Kazakhstan \\ ${ }^{3}$ Kazakh University of Economics, Finance and International Trade, 7 Zhubanov, Str., 010005, \\ Nur-Sultan, Kazakhstan
}

\begin{abstract}
The rapid development of Internet marketing has led to the fact that the active population has become independent of a permanent place of work. Flexible forms of employment have become more popular now, as they allowed the employees to work efficiently, realize their labor potential. The current constraints associated with the pandemic have further increased the relevance of telecommuting. The purpose of the article is to identify and classify the main factors contributing to the growth of the freelance market. To achieve the goal, the methods of analysis and synthesis were used in the framework of the structural-functional approach. The paper reflects the prerequisites and reasons for the emergence of freelancing, and outlines the socio-economic role of freelancing in solving modern problems of employment. The conditions favorable for the active development of the freelance services market are considered, which were classified into price and non-price conditions. Particular attention is paid to the impact of the Internet on the development of freelance services. The authors proposed factors in the freelance market, represented by primary factors, demand factors, supply factors and factors of an individual nature. Within each group they are investigated and substantiated. These factors allowed the authors to form and identify measures aimed at stimulating the development of the freelance market in Kazakhstan. They also proposed to create a multifunctional Internet exchange and gave recommendations to determine its functionality and main characteristics. The implementation of them will provide the freelance market with the necessary digital platform.
\end{abstract}

Keywords: freelance, freelancers, freelance services market, Internet, price advantages, non-price advantages, remote work, labor market.

For citation: Abdreissova, D.Zh., Baytenizov, D.T., Azatbe, T.A., \& Valieva, S.N. (2021). Freelance Market Development Factors. Economics: the Strategy and Practice, 16(4), 188-207, https://doi.org/10.51176/1997-99672021-4-188-207

* Corresponding author: Abdreissova D.Zh. - 2nd year doctoral student of the specialty "Economics", M.Kozybaev North Kazakhstan University, 150000, Republic of Kazakhstan, Petropavlovsk, 86 Pushkin Str., 87711067228, e-mail: diana_gmu05@mail.ru

Conflict of interests: the authors declare that there is no conflict of interest.

Financial support: The study was not sponsored (own resources).

The article received: 01.12 .2021

The article approved for publication: 29.12 .2021

Date of publication: 30.12 .2021 


\title{
Фриланс-қызметтер нарығын дамыту факторлары
}

\author{
Абдреисова Д.Ж. ${ }^{*}$, Байтенизов Д. Т. ${ }^{1}$, Азатбек Т.А. ${ }^{2}$, Валиева С.Н. ${ }^{3}$ \\ ${ }^{1}$ М.Қозыбаев атындавы Солтүстік Қазақустан университеті,Пушикин к., 86,150000, Петропавл, \\ Қазақстан \\ ${ }^{2}$ Л.Н. Гумилев атындавы Еуразия ұлттық университеті, Сәтбаев к., 2,010000, Нұр-Сұлтан, \\ Қазақстан \\ ${ }^{3}$ Қазақ экономика, қаржы және халықаралық сауда университеті, Жұбанов к., 7, 010005 , \\ Нұр-Сұлтан, Қазақстан
}

\begin{abstract}
Түйін
Ақпараттық технологиялардың қарқынды дамуында қалыптасқан әлемдік үрдістер, атап айтқанда, интернет-маркетингтің дамуы белсенді халықтың негізгі бөлігінің тұрақты жұмыс орнынан тәуелсіз болуына әкелді. Жұмыспен қамтудың икемді түрлері қазіргі заманда кеңінен танымал болды, өйткені олар қызметкерге барынша тиімді жұмыс істеуге, оның еңбек әлеуетін іске асыруға және жұмысынан анағұрлым жоғары қанағаттануға мүмкіндік берді. Пандемиямен байланысты заманауи шектеулер қашықтан жұмыс істеудің өзектілігін одан әрі арттыра түсті. Мақаланың мақсаты фриланс-қызметтер нарығының өсуіне ықпал ететін негізгі факторларды анықтау және олардың сыныптамасын жүзеге асыру болып табылады. Қойылған мақсатқа қол жеткізу үшін құрылымдық-функционалдық тәсіл шеңберінде талдау және синтез әдістері қолданылды. Жұмыста фриланстың пайда болуының алғышарттары мен себептері көрсетілген, сонымен қатар, жұмыспен қамтудың заманауи мәселелерін шешудегі фриланстың әлеуметтік-экономикалық рөлі айқындалған. Фриланс қызметтері нарығының белсенді дамуына оң ықпал ететін шарттар қарастырылған, олар бағалық және бағалық емес шарттарға жіктелген. Фриланс қызметтерін дамытуға интернеттің әсер етуіне ерекше назар аударылған. Авторлар факторлардың 4 тобымен ұсынылған фриланс нарығы факторларының жүйесін ұсынды: бастапқы факторлар, сұраныс факторлары, ұсыныс факторлары және жеке сипаттағы факторлар. Сонымен қатар, әр топтағы факторлар зерттеліп, негізделген. Зерттеу барысында анықталған факторлар авторларға Қазақстандағы фриланс нарығының дамуын ынталандыруға бағытталған шараларды қалыптастыруға және анықтауға мүмкіндік берді. Зерттеу шегіндежартылай функционалды интернет-биржаны құру ұсынылып, оның функционалдығы мен негізгі сипаттамаларын анықтау бойынша ұсыныстар берілді. Ұсынылған ұсыныстарды жүзеге асыру фриланс нарығын қажетті цифрлық платформамен қамтамасыз етуге мүмкіндік береді.
\end{abstract}

Түйін сөздер:фрилансер, фрилансерлер, фриланс қызметтер нарығы, Интернет, баға артықшылықтары, бағалық емес артықшылықтар, қашықтан жұмыс, еңбек нарығы.

Дәйексөз алу үшін: Абдреисова Д.Ж., Байтенизов Д.Т., Азатбек Т.А., Валиева С.Н. (2021). Фриланс-қызметтер нарығын дамыту факторлары. Экономика: стратегия және практика, 16(4), 188-207, https:// doi.org/10.51176/1997-9967-2021-4 -188-207

* Хат-хабаршы авторы: Абдреисова Д.Ж. - «Экономика» мамандығының 2 курс докторанты, Қозыбаев атындағы Солтүстік Қазақстан университеті, Пушкин к., 86, 150000, Петропавл, Қазақстан,e-mail: diana gmu05@mail.ru

Мүдделер қақтығысы: авторлар мүдделер қақтығысының жоқтығын мәлімдейді.

Қаржыландыру. Зерттеу демеушілік қолдау көрсеткен жоқ (меншікті ресурстар).

Мақала редакцияға түсті: 01.12 .2021

Жариялау туралы шешім қабылданды: 29.12.2021

Жарияланды: 30.12 .2021 


\title{
Факторы развития рынка фриланс-услуг
}

\author{
Абдреисова Д.Ж. ${ }^{*}$, Байтенизов Д. Т. ${ }^{1}$, Азатбек Т.А. ${ }^{2}$, Валиева С.Н. ${ }^{3}$ \\ ${ }^{1}$ Северо-Казахстанский университет им. М.Козыбаева, ул. Пушкина, 86, 150000, Петропавловск, \\ Казахстан \\ ${ }^{2}$ Евразийский национальный университет им. Л.Н. Гумилева, ул. Сатпаева, 2,010000, Нур-Султан, \\ Казахстан \\ ${ }^{3}$ Казахский университет экономики, финансов и международной торговли, ул. Жубанова, 7, \\ 010005, Нур-Султан, Казахстан
}

\begin{abstract}
Аннотация
Сложившиеся мировые тенденции стремительного развития информационных технологий, в частности развитие интернет-маркетинга, привели к тому, что основная масса активного населения стала независима от постоянного места работы. Гибкие формы занятости в наше время стали более популярными, так как позволили работнику максимально эффективно трудиться, реализовывать свой трудовой потенциал и максимально получать удовлетворение от работы. Современные ограничения, связанные с пандемией, еще больше усилили актуальность удаленной работы. Цель статьи - определить и осуществить классификацию основных факторов, способствующих росту рынка фриланс-услуг. Для достижения цели в работе использовались методы анализа и синтеза в рамках структурно-функционального подхода. В работе отражены предпосылки и причины возникновения фриланса, а также обозначена социально-экономическая роль фриланса в решении современных проблем обеспечения занятости. Рассмотрены условия, благоприятствующие активному развитию рынка фриланс-услуг, которые впоследствии были классифицированы на ценовые и неценовые условия. Особое внимание в статье уделяется влиянию интернета на развитие фриланс-услуг. Авторами предложена система факторов рынка фриланса, представленная 4 группами факторов: первичными факторами, факторами спроса, факторами предложения и факторами индивидуального характера. Кроме того, исследованы и обоснованы факторы внутри каждой группы. Выявленные в ходе исследования факторы позволили авторам сформировать и обозначить меры, направленные на стимулирование развития рынка фриланса в Казахстане. В рамках исследования предложено создание полифункциональной интернет-биржи и даны рекомендации по определению ее функционала и основных характеристик. Реализация предложенных рекомендаций позволит обеспечить рынок фрилансеровнеобходимой цифровой платформой.
\end{abstract}

Ключевые слова: фриланс, фрилансеры, рынок фриланс-услуг, Интернет, ценовые преимущества, неценовые преимущества, удаленная работа, рынок труда.

Для цитирования: Абдреисова Д.Ж., Байтенизов Д. Т., Азатбек Т.А, Валиева С.Н. (2021) Факторы развития рынка фриланс-услуг. Экономика: стратегия и практика, 16(4), 188-207, https://doi.org/10.51176/1997-99672021-4-188-207

* Корреспондирующий автор: Абдреисова Д.Ж. -докторант 2 курса специальности «Экономика», Северо-Казахстанский университет им. М.Козыбаева, ул. Пушкина, 86, 150000, Петропавловск, Казахстан, 87711067228, e-mail: diana_gmu05@mail.ru

Конфликт интересов: авторы заявляют об отсутствии конфликта интересов.

Финансирование. Исследование не имело спонсорской поддержки (собственные ресурсы)

Статья поступила в редакцию: 01.12.2021

Принято решение о публикации: 29.12.2021

Опубликовано: 30.12 .2021 


\section{Введение}

В результате трансформации рыночной экономики Казахстана появились новые нестандартные формы занятости населения. Пандемия и связанная с нею нестабильная ситуация в мировой экономике стали причинами падения спроса на труд и становления фриланса как альтернативой формы традиционной занятости населения. Фрилансер (перевод с анг. Freelancer - это наемный работник) - специалист, который выполняет услуги без заключения трудового договора для выполнения определенных обязательств. Сфера фриланс услуг, динамично развиваясь, стала важным сегментом рынка труда. Она имеет тенденцию к долгосрочному росту, так как увеличивается конкуренция как между заказчиками, так и между фрилансерами, расширяется информированность о квали-фицированных специалистах на мировом рынке фриланс услуг.

В Казахстане рынок фриланс-услуг развивается быстрыми темпами, хотя само понятие «рынок фриланс-услуг» не распространено ни в научной литературе, ни в экономической практике. Данное обстоятельство актуализирует необходимость проведения исследования и обоснования теории развития рынка фриланс-услуг.

\section{Литературный обзор}

Привлекают внимание в аспекте проблематики нашего исследования работы, посвященные изучению сущности и роли самозанятости в экономике. В их числе можно выделить работу Л. Шарпа и других ученых, в котором исследуется влияние финансового кризиса 2008 года на самозанятость в европейских странах. По их заключению, произошедшие изменения побудили специалистов решать проблемы занятости посредством оказания сдельных услуг, не оформляя трудовые отношения с работодателем. В посткризисный период именно эти самозанятые люди внесли огромный вклад в восстановление рынка труда в тех странах. Выделяя самозанятость в качестве одного из факторов устойчивого развития, авторы подчеркнули важность поощряющих ее мер и устраняющих препятствия ее развития [1].

А. Ирмижа, И. Лейбус рассматривают самостоятельную занятость как форму занятости, дающей человеку большую свободу с повышенным риском. Ими обозначены действующие меры и спектры политик, поддерживающие самозанятость в европейских странах. К мерам, благоприятно воздействующих на состояние самозанятости, они относят финансовую поддержку, субсидии, ссуды или микрокредиты, а также консультации и рекомендации. Авторы приходят к выводу, что влияние и поддержка государственной власти играют важную роль в развитии самозанятости [2].

Относительно молодой, и перспективной формой самозанятости выступает фриланс. Считается, что первым этот термин упомянул известный британский писатель В. Скотт в своем историческом романе «Айвенго» для описания «средневекового наемного воина» [3].Одна из первых трактовок термина «Freelance» в Оксфордском словаре гласила, что фрилансерами называли средневековых наемников, которые являлись профессиональными военными, свободными людьми и оказывали услуги за вознаграждение знатным людям ${ }^{1}$.

А.Шевчук, Дж. Бенсон, М. Браун определяют фриланс как самостоятельную деятельность квалифицированных профессионалов в творческой, управленческой, научной и технической областях $[4,5]$. Американский исследователь Д. Пинк к категории фрилансеров относил широкий спектр профессий, а именно от интеллектуального, творческого труда (программисты, дизайнеры и т.д.) до представителей физического труда (строители и т.д.) [6].

Особого внимания заслуживает определение Д.О. Стребкова и А.В. Шевчука, согласно которому «фрилансер» - это независимый профессионал высокой квалификации, не состоящий в штате организации и не участвующий в традиционных трудовых отношениях, самостоятельно реализующий свои услуги на рынке различным клиентам, не являясь субподрядчиком единственного заказчика [7].

Согласно научной позиции П. Лейгхтон и других авторов, в настоящее время большинство организаций используют труд фрилансеров для оказания определенных услуг, которые имеют жизненно важное значение для поддержки отношений с клиентами, репутации и идентичности бренда, в то время как компании не уделяют внимания на организационные моменты исполнения данного заказа и на мотивацию фрилансера. Фрилансеры, не являющиеся сотрудниками компаний, часто являются самым важным скрытым ресурсом организации. Авторы выделяют, что фрилансеры сейчас не являются нетипичными или

\footnotetext{
${ }^{1}$ Оксфордский словарь английского языка. URL: http://www.oxforddictionaries.com/definition/ english/freelance $>$.
} 
второстепенными, они все еще находятся в тени с точки зрения доступной литературы о том, как лучше всего их развивать и мотивировать [8].

А. Бурке и М. Коулин исследовали влияние труда фрилансеров на доход предприятия. Они обнаружили, что организации, использующие труд фрилансеров, могут достичь дополнительного роста продаж при $11 \%$ массе фрилансеров в своем штате. Данное открытие имеет некоторую интуитивную привлекательность, однако требует дальнейших исследований причин и процессов, приводящих к такому результату [9]. Также эти ученые анализировали увеличение на рынке фриланса развитых стран индивидуальных предпринимателей, которые сыграли трансформирующую роль в экономике. Исследователи приходят к выводу, что фрилансеры-одиночки, работающие не по найму, имеют все более высокий уровень образования и играют ключевую роль в стимулировании инноваций, предпринимательства и создании рабочих мест [9].

В. Журавлёв и другие авторы занимались разработкой модели поведения на рынке фрилансеров, основанной на поиске возможных путей совершенствования существующей системы. В их работе рынок фриланса смоделирован как непрерывный процесс с разными агентами, который реагирует поразному на несколько моделей поведения агентов (фрилансеров, заказчиков и т.д.). Кроме того, ими приведены и проанализированы различные стратегии, целью которых является получение прибыли агентами [10].

Важные выводы сделаны в рамках исследования К. Кранфорда и других авторов, рассматривающих проблемы канадского рынка фриланса, для которого характерны отсутствие прав на базовые гарантии и прав в сфере труда, такие как минимальная заработная плата, отпуск и пособия по беременности и родам и по уходу за ребенком, равенство в опла-те труда, безопасные и здоровые условия труда и доступ к коллективным переговорам. Ученые обоснавали, что политические и социальные реалии ограничивают коллективные действия фрилансеров и создают огромные препятствия для профсоюзов, пытающихся их организовать. Авторы утверждают, что необходимо расширить права на ведение коллективных переговоров и способы взаимодействия политических и экономических условий с классом, этнической принадлежностью и полом [11].

E.M. Акхметшин и другие авторы на основе проведенных социологических опро- сов и анализов статистических данных выявили положительные и отрицательные стороны развития фриланса в мировой экономике. Главным недостатком был определен неотработанный механизм взаимодействия агентов в этой сфере [12].

В своей работе О. Гримов рассматривал социально-экономическую и социокультурную природу фриланса как нетипичную форму занятости, созданную информационной сетевой экономикой. Нестандартная трудовая деятельность выражается в реализации свободы, независимости и творчества. В данном исследовании выявлена гибкость внештатной работы, и способность ее адаптировать уязвимые слои населения (пенсионеры, инвалиды и женщины, находящиеся в декрете). Автор пришел к заключению, что современный фриланс соответствует вызовам современного информационного общества и его базовым требованиям к человеку и организации как участникам экономического сотрудничества [13].

С.Г. Абсалямова и Т.Б. Абсалямов рассматривая вопросы влияния информационных технологий на рынок фриланса в период перехода к постиндустриальному обществу, пришли к выводу, что это дало развитие виртуального пространства для работы, сформировало Интернет-экономику, соответствующие развитию электронных рынков, электронного бизнеса. В данных условиях молодежь стала активной мобильной социально-демографической группой, рассматривающей фриланс как дополнительный источник дохода [14]. С мнением этих ученых солидарна Е.M. Афанаскина, которая отметила, что фрилансеры в современном обществе работают дистанционно, обычно используя современные информационно-коммуникационные технологии [15]. Бычков А. определяет фрилансеров как молодую группу онлайн-профессионалов, оказывающих услуги в сфере интеллектуального и творческого труда, стремящиеся к самостоятельной организации своего рабочего времени для достижения большей независимости и пространственной локализации. Кроме того, они постоянно находятся в перманентном состоянии поиска новых способов заработка [16]. Развивая данную мысль, Baitenizov, D. T. и другие авторы в своей обзорной статье определили фриланс как новую и продвинутую форму и способ самозанятости, a также выявили тенденции и перспективы развития самозанятости в контексте процессов глобализации и формировании новой экономики. Авторы пришли к выводу о том, 
что фриланс дает толчок к формированию и развитию инновационной самозанятости [17].

Дж. Меркель считает, что растущее число коворкинг-пространств является поддерживающим звеном фрилансеров. Автором дано определение фрилансерам - это «невидимая» рабочая сила, влияние которой часто остается «скрытой». Данная категория самозанятых не защищена на законодательном уровне о социальном обеспечении, соответственно не пользуется такими же социальными правами, как наемные работники [18].

Существуют различные точки зрения, характеризующие основные факторы возникновения фриланса. Например, И. СсуллиРусс, Р. Торросо отмечали, что под воздействием экономических, демографических, технологических и других факторов меняется состав и доступность рабочих мест. В их статье исследуются факторы, обуславливающие появление фриланса, и исследуются новые возможности, которые авторы предлагают для трудоустройства и получения дохода. Предложена синтезирующая модель исследования развития человеческих ресурсов и роста фриланса для теории и практики [19].

C. Хеусч анализирует влияние различных факторов (экономических, социальных, политических и нормативных) на возникновение фриланса. По его мнению, фриланс находится в серой зоне занятости, так как нормативно-правовая база Европы создает одинаковые трудности для тех, кто ищет баланс между свободой развития экономической деятельности и доступом к социальной защите. Подробно описаны трудности, с которыми сталкивается фрилансер: нерегулярность, низкий доход; ограниченный денежный поток; и трудности с получением доступа к обучению и социальной защите и т.д., с целью выявления возможных подходов к их включению в механизмы социальной защиты [20].

Р. Ремеикиене и Г.Стартиене в своей работе описали влияние факторов институциональной среды на самозанятость в странах с переходной экономикой. К факторам, оказывающим положительное влияние, удлиняющие продолжительность самозанятости они отнесли упрощенные процедуры открытия бизнеса и государственные меры поддержки бизнеса. Неравенство в социальных гарантиях, барьеры для выхода на рынок они признали отрицательными факторами. Негативное влияние на продолжительность самозанятости оказывают такие факторы, как частые корректировки в налоговом законодательстве, коррупция и теневая экономика [21].

К.В. Дрокина, исследуя факторы, влияющие на развитие рынка фриланса в России, выделила основные преимущества фриланса для работодателей и разделила их на три основные группы: общие факторы, факторы спроса и предложения. Подводя итоги, автор отметила, что максимальная свобода торговли от влияния государства могут привести к отрицательным результатам, а именно к увеличению численности самозанятого населения в теневом секторе экономики, отсутствию социального пакета для фрилансеров и т.д. [22].

В работе Б.Ж. Тагарова отражены факторы развития рынка фриланса в информационной экономике, которые подразделены на две группы: факторы спроса и предложения. В рамках факторов спроса рассмотрены сетевая структура фирмы, проектный характер работ, высокий уровень мотивации фрилансеров к эффективному труду, возможность снижения затрат и т.д. К факторам предложения автор отнес рост мобильности населения, рост качества жизни, независимость доступа к знаниям от географического местоположения, нехватка рабочих мест и низкий доход в периферии и т.д. Основные выводы исследования заключаются в том, что увеличение числа фрилансеров на рынке связано с желанием быть независимым от работодателя, повысить свой уровень жизни за счет быстрого и качественного выполнения заказов и стремлению самореализации посредством получения новых навыков и образования [23].

Исследуя социальные факторы появления фрилансеров в структуре занятого населения О.В. Полетаева отмечает их неравномерное распределения по профессиональным, территориальным, социальнодемографическим сегментам. Исследователь отмечает, что к технологическим факторам (внедрение информационно-коммуникационных технологий) также добавляется и социальные факторы, а именно необходимость работодателя обращаться на рынок фриланса для поиска специалистов и социально-демографическая ситуация, которая характеризуется естественной убылью и старением населения [24].

Особое внимание также уделяется развитию фриланса в условиях пандемии COVID-19. В частности, Stephany, F. и другие авторы анализируют данные OnlineLaborIndex и интервью с фрилансерами в США, чтобы отразить последствия влияния пандемии 
COVID-19 на рынок фриланса. В период пандемии многие сотрудники перешли во фриланс. Авторы определили существенные различия между странами и профессиями. Данные интервью и онлайн-опросов показывают, что вакансий становится все меньше, несмотря на то, что все больше людей создают профили и ищут работу в Интернете [25].

В целом, исследованию сущности фриланса, предпосылок и проблем его развития было посвящено обильное количество работ. В то же время научная проработанность вопросов, связанных с определением факторов, влияющих на становление рынка фирланс-услуг остается невысокой. Практически отсутствуют исследования, комплексно рассматривающих эти факторы. Эти обстоятельства обуславливают необходимость систематизации факторов и условий развития рынка фриланса.

\section{Методы исследования}

Исследование проведено с позиции структурно-функционального подхода, базирующегося на методах анализа и синтеза в рамках исследования процесса появления фрилансеров в структуре занятого населения с целью анализа и обобщения статистической информации, выявления тенденций и особенностей рынка фриланс-услуг.

Ход исследования состоял из следующих этапов:

1. На основе обобщения результатов ранее проведенных исследований другими учеными, сформирована теоретическая база, которая была подвергнута анализу с посредством использования системно-логического и сравнительного методов исследования, для выявления причин возникновения фриланса, проблем решаемых фрилансом.

2. Изучены общественные функции фриланса как нового направления самозанятости. Определены факторы, способствующих росту рынка фриланс-услуг.

3. Проведен анализ первичных факторов, факторов спроса и предложения, а также индивидуальных факторов, влияющих на развития рынка фриланс-услуг.

Информационной базой исследования выступили монографии, учебники, научные статьи по теме исследования, результаты опросов, проведенных компаниями $\mathrm{EY}$ и PwC, данные ИТ-холдинга TalentTech, НИУ ВШЭ и биржи фриланса FL.ru, а также данные Бюро национальной статистики Агентства по стратегическому планированию и реформам РК (БНС АСПР РК). Поскольку статистические показатели рынка фриланса РК отсут- ствуют, в работе для обозначения и проецирования общих тенденций, были использованы данные по миру и России. Кроме того, для изучения рынка фрилансуслуг, авторы использовали данные мировых и казахстанских интернет-платформ, размещающих информацию о вакансиях для фрилансеров.

\section{Результаты и обсуждение}

Показатель уровня безработицы в мае 2020 года во многих странах мира, в том числе и развитых достиг критического уровня, например, в США он составил 14\%, а в Индии свыше 27\%.В Казахстане за 2020 год было 448,8 тыс. человек $(1,5 \%)$ официально зарегистрированных безработных, а до начала пандемии - 440,7 тыс. человек $(1,1 \%)^{2}$.

Происходящие изменения в мире и в экономике сподвигли большое количество специалистов задуматься в каком сегменте экономики они могли бы оказывать онлайн услуги (таблица 1). Так, на глобальной фриланс-бирже KWork произошло резкое увеличение количества новых пользователей и составило 4,3 миллиона человек в 2020 году, что больше на 3 миллиона человек в 2019 году [26].

Таблица 1 - Зарегистрированные пользователи на фриланс-бирже KWork

Table 1 - Registered users on the freelance exchange Kwork

\begin{tabular}{|c|c|c|}
\hline Период & чел. & $\begin{array}{c}\text { Темп прироста } \\
(\mathbf{\%})\end{array}$ \\
\hline 2016 & 100000 & - \\
\hline 2017 & 320000 & 220 \\
\hline 2018 & 705000 & 120 \\
\hline 2019 & 1300000 & 84 \\
\hline 2020 & 4300000 & 230 \\
\hline
\end{tabular}

Примечание - Источник [25].

Как видно из таблицы 1, в 2020 году произошел резкий рост числа фрилансеров, что обусловлено влиянием пандемии и связанных с ним карантинных ограничений. Стараясь адаптироваться к резким изменениям, казахстанцы активно изучают рынок онлайн-занятости. Для многих спасением стал фриланс. Согласно сервису поисковых запросов Wordstat, в марте в стране наблюдается

\footnotetext{
2 Бюро национальной статистики Агенства по стратегическому планированию и реформам Республики Казахстан; 2021 [обновлено 13 февраля 2021; процитировано 5 сентября 2021]. Доступно: https://stat.gov.kz/for_users/dynamic
} 
увеличение поиска по слову «фриланс» почти на $45 \%$ (таблицы 2, 3).

Таблица 2 - Сайты вакансий для поиска удаленной работы в Казахстане (по данным на 28 августа 2020 года)

Table 2 - Job sites for finding remote work in Kazakhstan (as of August 28, 2020)

\begin{tabular}{|c|c|}
\hline Сайт & Количество вакансий \\
\hline hh.kz & 27140 \\
\hline trudbox.kz & 3116 \\
\hline rabota.yandex.ru & 2008 \\
\hline gyzmet.kz & 1162 \\
\hline olx.kz/rabota & 748 \\
\hline market.kz & 638 \\
\hline
\end{tabular}

Примечание - Составлено авторами на основе анализа интернет-порталов

Помимо вышеуказанных в таблице сайтов, существуют и другие биржи фрилансеров (таблица 3).

Таблица 3 -Биржи фрилансеров Table 3 - Freelance exchanges

\begin{tabular}{|c|c|c|}
\hline $\begin{array}{c}\text { Мировые } \\
\text { биржи } \\
\text { фрилансеров }\end{array}$ & $\begin{array}{c}\text { Биржи } \\
\text { фрилансеров } \\
\text { стран СНГ }\end{array}$ & $\begin{array}{c}\text { Казахстанские } \\
\text { биржи } \\
\text { фрилансеров }\end{array}$ \\
\hline Upwork & Fl.ru & Allfreelance.kz \\
\hline Designhill & Weblancer.net & Ozat.kz \\
\hline Skyword & Freelance.ru & Megamaster.kz \\
\hline TaskRabbit & $\begin{array}{c}\text { Freelancehunt. } \\
\text { com }\end{array}$ & Freelancehunt.kz \\
\hline WriterAccess & FreelanceJob & Uwork.kz \\
\hline Freelancer & ХабpФpиланс & \\
\hline Aquent & Kwork & \\
\hline Nexxt & Workspace & \\
\hline Fiverr & Upwork & \\
\hline Toptal & Free-lancers.net & \\
\hline $\begin{array}{l}\text { Примечание - Cocтавлено авторами на основе } \\
\text { анализа интернет-порталов }\end{array}$
\end{tabular}

Развитие рынка-фриланса, профессиональных фриланс-сообществ и наличие на фриланс-платформах огромного количества онлайн-сотрудников в Интернете дает возможность клиенту выбрать подходящего исполнителя в соответствии со всеми требованиями. Большинство фрилансеров, это люди, которые имеют способность самостоятельно организовывать свой рабочий день, осуществлять контроль своего времени и энергии, от которых зависит их эмоциональное состояние. Зарекомендовавший себя на рынке фриланс-услуг внештатный сотрудник может позволить себе выбирать заказчиков и проекты, в которых бы он хотел принять участие. Такие преимущества удаленной работы как наличие гибкого графика позволяют специалисту больше и продуктивнее уделять время на семью.

Опираясь на исследования зарубежных экономистов и социологов, можно сделать выводы, что современные работники рынка фриланса отдают предпочтения в своей работе прагматическим ценностям, таким как доход, удобный график, возможность работать не выходя из дома, возможность не отрабатывать стандартный рабочий день [27].

Удаленная работа помогает решить множество современных проблем, с которыми сталкиваются сотрудники. Работодатель, используя труд наемных специалистов, получает ряд положительных преимуществ: экономия на аренде, коммунальных платежах, на налогах, на организации рабочего места и т.д. Данная экономия позволяет заказчику сохранять занятость в кризисном состоянии фирмы. Эта система, устраняющая ряд транспортных проблем, благоприятно повлияла на экологическую обстановку [28, c. 292].

Фрилансер старается выполнять свои заказы значительно быстрее и качественнее, так как от этого зависит его репутация и клиентская база. В случае недобросовестного исполнения заказов фрилансер получает отрицательные отзывы, которые будут отражены на фриланс-сообществах. Это приведет к сокращению заказов и потери карьеры. Заказчик, обращаясь на биржи самозанятых, стремится найти новые знания и опыт, которыми не обладают его штатные сотрудники.

Фриланс - это возможность самореализоваться и решить проблемы таким категориям граждан как молодые мамы и люди, имеющие проблемы со здоровьем. Онлайн-занятость способствует повышению уровня жизни маломобильного населения. Проблема таких людей заключается в неспособности вести обычную трудовую деятельность в офисе. Для них фриланс - это шанс работать дома в удобных для здоровья условиях.

С помощью удаленной занятости можно решить проблемы моногородов, которые заключаются в падении уровня жизни трудоспособного населения из-за снижения спроса на продукты, изготавливаемые в одном или нескольких градообразующих предприятиях. Фриланс является одним из 
решений проблемы трудоустройства людей в моногородах.

В настоящее время во многих развивающихся странах мира государственными органами не ведется статистический учет фрилансеров, они часто работают неофициально. Исследователи для получения данных по фрилансу проводят онлайнопросы и переписи фрилансеров, что позво- ляет оценить их количественный и качественный состав.

Вышеизложенное

подчеркивает необходимость обстоятельного рассмотрения вопроса о причинах развития фриланса, тем самым разделив факторы, обуславливающие рост фриланса на три группы: первичные факторы, факторы спроса, факторы предложения, факторы индивидуального характера (рисунок 1).

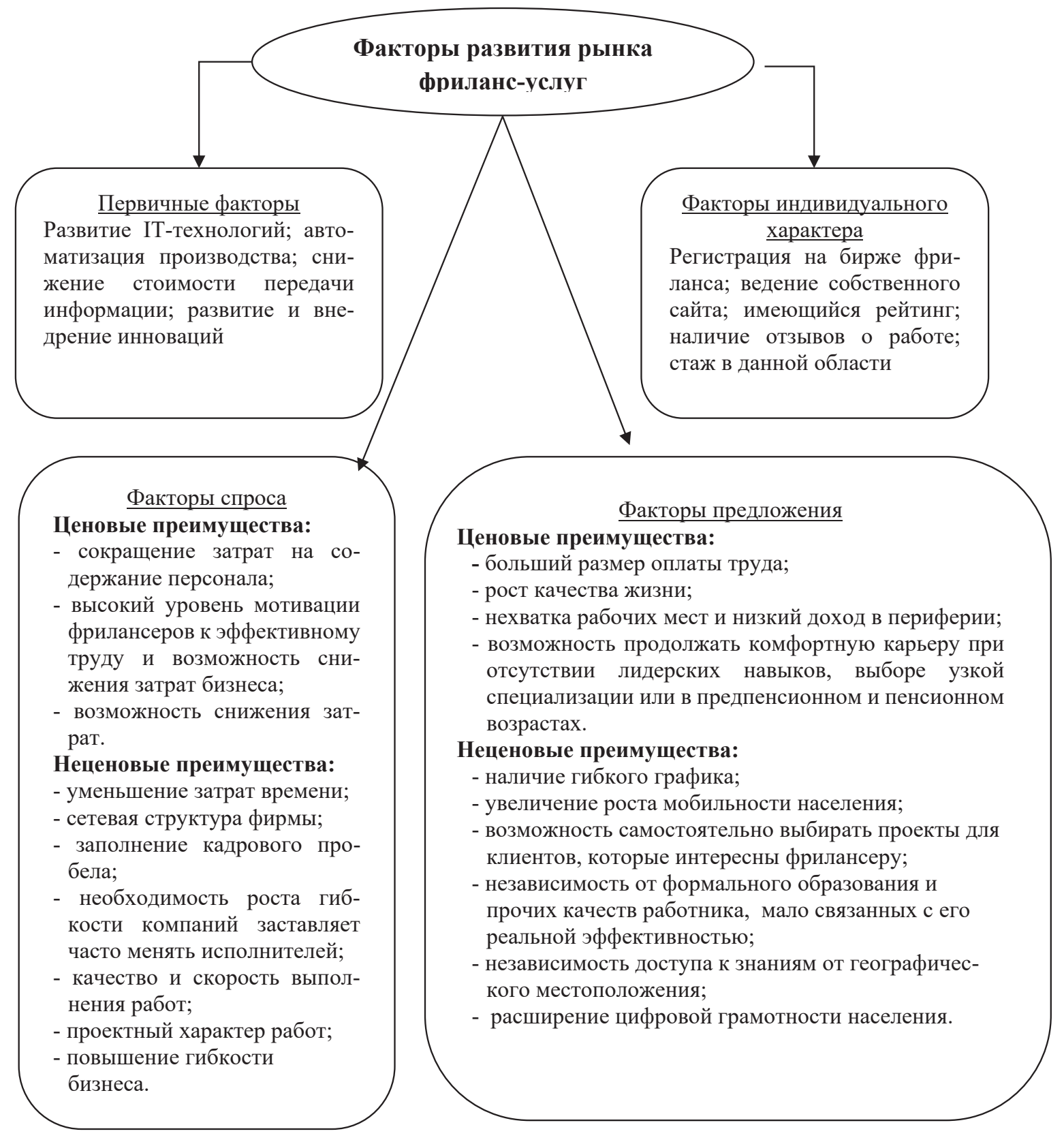

Рисунок 1 - Факторы, обуславливающие рост фриланса в современной экономике

Figure 1 - Drivers of Freelance Growth in the Modern Economy

Примечание - Составлено авторами на основе источника [22,23, 24]. 


\section{Первичные факторы}

Зарождение фриланса связано со стремительным развитием информационнокоммуникационных технологий. Развитие Интернета привело к тому, что фрилансеры могут выполнять многие виды работ не зависимо от места и времени. В этих условиях наличие офиса не обязательно, так как его может заменить дом фрилансера. Смысл удаленной работы заключается в том, что фрилансер и заказчик могут физически не взаимодействовать друг с другом, a результаты труда фрилансера передаваться посредством сети Интернет. Развитию рынка фриланса способствовала также невысокая стоимость использования сети Интернет. В современной новой экономике упор делается на интеллектуальный творческий труд, носящий проектный характер. Поэтому организации для выживания в рамках жестокой конкуренции вынуждены создавать продукты ноу-хау [29]. С ростом цифровой грамотности населения связан рост рынка фриланс-услуг. Ежегодно количество пользователей сети Интернет увеличивается, и в январе 2020 года данный показатель по миру достиг уровня 4,54 миллиарда человек, что на $7 \%$ больше показателя января 2019 года. На 9\% по сравнению с 2019 годом выросло количество пользователей социальных сетей и составило 3,8 миллиарда человек, т.е 321 миллион новых пользователей прибавилось за один год. Прирост пользователей мобильных телефонов равен 124 миллиона человек, что составляет 5,19 миллиардов пользователей. По данным Digital 2020,в России количество пользователей Интернета составило 118 миллионов человек или $81 \%$ россиян[30]. В Казахстане в январе 2021 году 16 млн. абонентов сотовой связи имеют доступ к интернету. Это на 6,8\% больше, чем в предыдущем году. Также увеличилось число абонентов фиксированного интернета в стране на $5,1 \%$ за год, составив 2,6 млн. абонентов (таблица 4).

Таблица 4 - Численность абонентов с выходом к сети Интернет по сегментам в РК

Table 4 - The number of subscribers with access to the Internet by segments in the Republic of Kazakhstan

\begin{tabular}{|l|c|c|c|c|}
\hline \multirow{2}{*}{ Период } & \multicolumn{2}{|c|}{$\begin{array}{c}\text { Число абонентов сотовой связи с доступом } \\
\text { к интернету }\end{array}$} & \multicolumn{2}{|c|}{$\begin{array}{c}\text { Число абонентов фиксированного } \\
\text { интернета }\end{array}$} \\
\cline { 2 - 5 } & $\begin{array}{c}\text { количество } \\
\text { (млн. единиц) }\end{array}$ & $\begin{array}{c}\text { темп роста к итогу, } \\
\%\end{array}$ & $\begin{array}{c}\text { количество } \\
\text { (млн. единиц) }\end{array}$ & $\begin{array}{c}\text { темп роста к итогу, } \\
\%\end{array}$ \\
\hline Январь 2016 & 11 & 106 & 2,1 & 100,2 \\
\hline Январь 2017 & 12 & 108,4 & 2,4 & 111,2 \\
\hline Январь 2018 & 14,1 & 117,5 & 2,6 & 111,7 \\
\hline Январь 2019 & 14,4 & 102,4 & 2,5 & 101,0 \\
\hline Январь 2020 & 15,0 & 104,0 & 2,5 & 105,1 \\
\hline Январь 2021 & 16,0 & 106,8 & 2,6 & \\
\hline
\end{tabular}

Примечание - Источники [30,31].

Таким образом, количество пользователей сети Интернет во всех сегментах значительно возросло. Общий охват населения Казахстана интернетом составляет $99 \%$.

На первый взгляд, учитывая возможности, предоставляемыми глобальными биржами фрилансеров, казахстанцам можно было решить проблему трудоустройства. Однако, во-первых, не все трудоспособные казахстанцы свободно владеют английским языком. Но главный вопрос заключается в цифровом неравенстве среди казахстанцев. Ведь безработные сельские люди часто не имеют доступ к дешевому и скоростному интернету. Более того, достаточными цифровыми навыками обладают далеко не все.
По данным БНС АСПР РК показатель цифровой грамотности в Казахстане составил порядка 84\%. Не все регионы Казахстана достигли показателя данного уровня: Акмолинская область (74,9\%), СевероКазахстанская область $(78,8 \%)$, ЗападноКазахстанская область (78,8\%), Мангистауская область $(79,6 \%)$. В 2022 году, согласно государственной программе «Цифровой Казахстан», планируется достигнуть показатель в 83\%.Наивысший показатель достигнут в городе Алматы - 91,4\%. В остальных регионах уровень цифровой грамотности варьируется в пределах свыше 80\% [31]. Как видим, существуют региональные диспропорции в цифровой грамотности населения Казахстана. 
Факторы спроса.

Сокрашение затрат на содержание персонала

Постоянные издержки составляют большую часть всех затрат компаний. Поэтому многие компании стремятся сократить свои постоянные затраты, тем самым снизив себестоимость продукции, которая повлечет увеличение прибыли. Выделяют 4 способа сокращения издержек на персонал: уменьшение штата, изменение рабочего режима, уменьшение заработной платы и аутсорсинг. По данным онлайн-опроса британской аудиторско-консалтинговой компании Ernst\&Young, 15 крупных предприятийиз разных секторов экономики в период коронакризиса сократили постоянные и капитальные издержки более чем на $20 \%$. Большинство организаций рассматривают вариант сокращения своего штата за счет делегирования своих полномочий на аутсорсинг ${ }^{3}$.

В Казахстане сложившаяся кризисная ситуация вынуждает многие фирмы сократить расходы на персонал. Данный выход позволит предприятиям уменьшить затраты на заработную плату и обслуживание рабочего места.

Высокий уровень мотивации фрилансеров $\kappa$ эффективному труду и возможность снижения затрат бизнеса.

Работники компаний, выполняющие интеллектуальные и творческие работы, менее подвержены контролю со стороны руководства. Такие сотрудники являются в организации единственными в своей области,

не имеющие конкурентной борьбы. Их мотивация сводится только к желанию отличиться перед руководством. Благодаря мотивации, у фрилансера возникает стремление заниматься развитием своих профессиональных навыков и достигать поставленных целей. Согласно опросу, проведенному рекрутинговым агенством HeadHunter, фрилансеры ценят в своей работе возможность самостоятельно распределять свое время $(79 \%)$, экономию времени и денег на дорогу $(75 \%)$, работу без географической привязки (64\%), совмещение нескольких видов работ (47\%) [32]. На мотивацию фрилансера также может влиять и заказчик, осуществляющий ряд мероприятий, которые вызывают желание у онлайн-специалиста трудиться. К ним относятся: достойная оплата труда (основной мотиватор), интересный проект, четко сформулированное задание, премии,

\footnotetext{
Затраты на персонал и их эффективность. Энциклопедия управления персоналом, 2021 [обновлено 5 декабря 2016; процитировано 16 июля 2021]. Доступно: http://dps.smrtlc.ru/Od_PM/Od_03_3. htm
}

долгосрочное сотрудничество и свобода в действиях. Доход онлайн-сотрудника зависит от его репутации, которая складывается на основе всех выполненных проектов в специализированных биржах. В первое время начинающим фрилансерам необходимо заявить о себе. Для этого они вынуждены выполнять сложные заказы за относительно невысокую стоимость. На этом этапе одна часть недобросовестных фрилансеров отсеиваются, а другая часть нарабатывает себе положительное портфолио. Риском для внештатного сотрудника является потеря репутации и наличие отрицательных отзывов. Работодатель, оценивая фрилансера с помощью специальных бирж, нанимает внештатного сотрудника на выполнение проекта. При этом расход времени на поиск фрилансера минимизируется.

Высокий уровень мотивации фрилансеров позволяет бизнесу решать оперативно свои задачи, поэтому возникает спрос на таких фрилансеров. Этот взаимодействие является ключевым механизмом развития фриланса и предпринимательства.

Использование труда фрилансеров позволит решить основные четыре проблемы для бизнеса: повышение производительности труда, повышение эффективности проектов, снижение издержек на персонал и минимизация социального напряжения. В настоящее время работа с фрилансерами стала распространенной тенденцией в развитых странах. Согласно аналитическим прогнозам американской платформы UpWorkи Союза фрилансеров, более 50\% жителей США к 2027 году перейдут во фриланс. По данным онлайн-опроса $\mathrm{PwC}$, заместить фрилансерами до $30 \%$ штатных сотрудников планируют более $25 \%$ компаний. Крупные компании запускают свои электронные платформы для размещения предложений по выполнению проектов для фрилансеров (например, «Газпром нефть»). Согласно данным опроса, большую часть заказчиков фрилансеров составляю частные лица и предприятия (45\%), предприятия численность штата которых не превышает 50 сотрудников (39\%), предприятия численность штата свыше 50 человек $(16 \%)$. Из общей численности заказчиков только 26\% пользуются услугами фрилансеров на постоянной основе, оставшаяся часть - периодически. Анализ показал, что основной причиной вовлечения фрилансеров в производственный процесс является недлительное сотрудничество (69\%), большой выбор фрилансеров на специализированных биржах фриланса (50\%), невысокая оплата 
труда наемных специалистов (49\%), экономия на организационных моментах (35\%) [32].

Основными причинами перехода заказчиков на сотрудничество с фрилансерами является: снижение оплаты за аренду помещения, снижение расходов на организацию рабочих мест (оборудование, коммунальные услуги, транспорт, командировки), оплата фрилансеру в рамках определенного проекта по сниженной цене, отсутствие затрат на социальный пакет сотрудника, снижение управленческих издержек (мотивация, контроль и т.д.). Выбор такого подхода компаний выгоден и для региональных властей, так как он позволит в определенной степени решить транспортные проблемы [33].

Привлекая фрилансеров, бизнес экономит на налогах, на страховых взносах, на аренде рабочего места, на коммунальных затратах. Заказчик оплачивает только по результатам выполненной работы. Он освобождается от предоставления внештатным сотрудникам социального пакета, включая пенсионные и страховые отчисления, отпускных, больничных, а также не тратится на обучение и переобучение работников [34].

Уменьшение затрат времени

Фрилансер вынужден постоянно самостоятельно находить новые проекты, в которых он может принять участие. Активность, постоянство качества, умение демонстрировать и рекламировать свои успешные проекты, умение пользоваться специализированными интернет-ресурсами - такими характеристиками должен обладать фрилансер для успешного поиска заказов. Только при реализации всех этих способностей фрилансер сможет максимально эффективно управлять собственным временем. Положительной стороной удаленной интеллектуальной деятельности является исключение временных затрат на транспорт и выполнения поручений руководства, не относящихся к выполнению проектов. Фрилансер самостоятельно принимает решение о выполнении определенных обязательств и о выборе команды для совместной работы, не затрачивая при этом времени на выстраивание взаимопониманий между исполнителями. Заказчик, в свою очередь, также имеет возможность быстрого поиска исполнителей заказа и быстрого расторжения обязательств в случае нарушений условий договора. При этом работодатель экономит время на процедурах увольнения штатного сотрудника [35].

\section{Сетевая структура фирмь}

Обострение конкуренции на рынке обуславливают стремление руководителей организаций искать подходящие формы бизнеса для сохранения лидирующих позиций на рынке. Одним из таких решений является передача части бизнес-процессов во внешнюю среду сторонним подрядчикам. Данное решение может быть принято в том случае, если внутренние управленческие издержки организации будут выше рыночных трансакционных [36]. В таких условиях переход на аутсорсинг позволит конкурировать фирме на рынке, так как основной его целью является использование ноу-хау для завоевания конкурентных преимуществ. Положительным эффектом от аутсорсинга является то, что каждая из сторон может выполнять те функции, в которых она наиболее успешна [37].

\section{Заполнение кадрового пробела}

Из-за наличия дефицита квалифицированных специалистов работодатели вынуждены обращаться к рынку фрилансеров. По прогнозам $\mathrm{PwC}$, в 2025 году доля российских наемных специалистов в составе штата среднестатистической организации составит $20 \%$. В настоящее время более $50 \%$ компаний испытывают трудности с наймом компетентных сотрудников. В сложившейся ситуации обращение к труду онлайн-специалистов способствует быстрому исполнению работ, повышая при этом гибкость бизнеса и сокращая издержки [38].

Необходимость роста гибкости компаний заставляет часто менять исполнителей.

Из-за цифровизации и автоматизации компаниям выгоднее использовать труд фрилансеров. Так как организации нуждаются не в штатном сотруднике, а в конкретных функциях. На смену сложной иерархической организационной структуре приходит структура с горизонтальным взаимодействием. Причиной такой смены структуры является необходимость бизнеса адаптироваться к новым изменениям в экономике. Данная система имеет ряд преимуществ: возможность найма специалистов в своей сфере, возможность сменяемости подрядчиков, возможность быстрого расторжения отношений с фрилансерами и т.д.

Качество и скорость выполнения работ

Независимые работники заинтересованы в том, чтобы выполнить работу как можно быстрее и качественнее, это позволит им заработать, получить рекомендации заказчика и приступить к следующему проекту. В случае получения отрицательных отзывов это отразится на количестве заказов. 


\section{Проектный характер работ}

В новой информационной экономике деятельность многих современных компаний, занимающихся инновационной творческой деятельностью, организована по проектному принципу. Управление проектами на данный момент является одним из мощных инструментом создания новых продуктов и услуг. Фирме нужны внештатные сотрудники, которые создают спрос на рынке интеллектуального фриланса для выполнения определенных задач. Работа такого сотрудника оплачивается сдельно в зависимости от объема и сложности выполняемых им заданий в проекте.

\section{Повышение гибкости бизнеса}

Рынок фриланса растет как по числу фрилансеров, так и в большей степени по увеличению оборотов. Это говорит о том, что на рынок пришли не только фрилансеры, но и компании со своими предложениями и задачами по выполнению проектов. Использование труда фрилансеров позволяет бизнесу подстраиваться под меняющуюся деловую среду современного мира. Бизнес становится более адаптивным, креативным и жизнеспособным к меняющимся условиям. Согласно статистике Freelancer.com, в период влияния COVID-19 произошло увеличение предложений для фрилансеров на 14\% [39].

\section{Факторы предложения}

Больиий размер оплаты труда

Согласно исследованию, проведенного консалтинговой компанией $\mathrm{PwC}$, основная масса фрилансеров в России получают менее 30 тыс.руб. в месяц (таблица 5).

Таблица 5 - Доход фрилансеров в 2020 году Table 5 - Freelance income in 2020

\begin{tabular}{|l|c|}
\hline \multicolumn{1}{|c|}{ Доход } & Фрилансеры \\
\hline До 30 тыс. руб ( 171900 тенге) & $64 \%$ \\
\hline До 60 тыс. руб ( 343800 тенге) & $17 \%$ \\
\hline До 100 тыс. руб ( 573000 тенге) & $13 \%$ \\
\hline Более 100 тыс. руб (>573000 тенге) & $6 \%$ \\
\hline
\end{tabular}
Примечание - Источник [39].

В то же время в Казахстане среднемесячная заработная плата наемных работников по статистическим данным за апрель 2019 года составила: 0,1\% - до 30000 тенге; 3,3\% - от 30001 тенге до 45000 тенге; 22,7\% - от 45001 тенге до 75000 тенге; 20\% - от 75001 тенге до 105000 тенге; 39,5\% - от 105001 тенге до 240000 тенге; 14,3\% - от 240001 и выше. Таким образом, следует подчеркнуть, что $46,1 \%$ работников получали 3/п менее 105 тыс. тенге. В 2020 году почти каждый десятый самостоятельно занятый является непродуктивно занятым, т.е. доход такого самозанятого не превышает величины прожиточного минимума (31183 тенге)[40].

В целом, средний заработок фрилансеров всех специальностей в Казахстане вырос в период коронавирусной инфекции на $20 \%$ (рисунок 2).

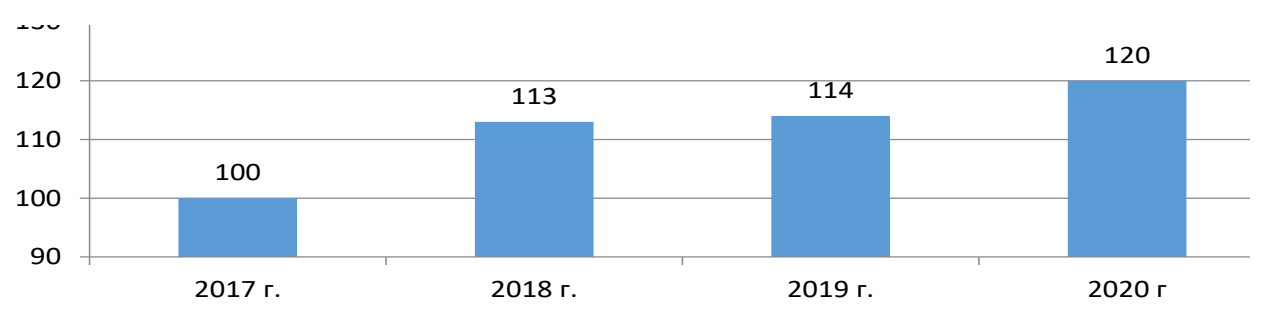

Рисунок 2 - Средний доход фрилансеров за год, тыс. тг. в месяц Figure 2 - Average income of freelancers per year, thousand tenge per month

Примечание - Составлено авторами на основе источника [41].

Занятие фрилансом, для многих кто совмещает с основным местом работы, может стать дополнительным заработком. Удаленная работа позволяет не тратиться на дорогу, на аренду офиса, на деловую одежду и т.п. Однако, фактор предложения недостаточно устойчив ввиду отсутствия фиксированного оклада, риска невыплаты за выполненный заказ, недоверия институтам власти, отсут- ствие социального пакета, простой в работе и неэффективность правовой системы.

\section{Рост качества жизни}

Развитие электронного фриланса, который в настоящее время является одним из перспективных направлений, позволит улучшить качество жизни населения. Занятие фрилансом дает возможность повысить доход населения, доступ к качественным 
медицинским услугам, уровень образования и другое. Фриланс это способ для людей с ограниченными возможностями повысить уровень жизни. Ценности фрилансеров зависят от уровня развитости страны, в которых они проживают. Цель фрилансеров, живущих в бедных странах, это получение высокого дохода, цель фрилансеров из развитых стран - это возможность самореализоваться, занимаясь любимым делом. По данным исследования Upwork 68\% фрилансеров, проходивших онлайн-опрос отметили, что их качество жизни улучшилось с приходом на рынок онлайн-услуг [42].

Нехватка рабочих мест и низкий доход в периферии

Различия в оплате труда существуют как между разными государствами, так и внутри государства по регионам. Уровень заработной платы в разных регионах страны отличается, поскольку стоимость труда внештатных сотрудников разной квалификации в различных регионах оцениваются поразному, Фрилансерам, доход которых относительно невысок, выгодно «жить дома» и оказывать услуги через интернет. Для онлайнспециалистов, проживающих в государствах с низким уровнем жизни, где показатель уровня безработицы высок, фриланс дает возможность улучшить качество жизни. Большая часть внештатных сотрудников приходят во фриланс из стран с высоким уровнем безработицы. Другая часть фрилансеров это люди, не имеющие физической возможности полноценно работать в офисе на постоянной основе: студенты, женщины, находящиеся в декретных отпусках, пенсионеры, инвалиды и прочие.

Возможность продолжать комфортную карьеру при отсутствии лидерских навьков, выборе узкой специализачии или в предпенсионноми пенсионном возрастах

Комфортные условия труда обусловлены способностью фрилансера создавать благоприятные условия для своей работы (персонализированное рабочее место, одежда, питание, температура и т.п.) и оптимизировать баланс между семьей, отдыхом и работой. Фрилансер самостоятельно определяет распределение своего времени. Ему необходимо придерживаться своего режима, при котором, согласно принципу Парето, 20\% усилий дают $80 \%$ результатов [43]. Для рынка фриланса возраст не имеет никакого значения, главное - соответствующая квалификация. Этим фриланс и отличается от работы в офисе.

\section{Наличие гибкого графика}

Наличие гибкого графика является главным преимуществом удаленной работы. Удаленные работники, работая во фриланс, имеют возможность совмещать несколько работ и участия в нескольких проектах.

Увеличение роста мобильности населения

C каждым годом население планеты становится все более мобильным. Частично это связано с развитием рынка фриланса, так как доход этого мобильного населения не зависит от местоположения. В последние годы большинство фрилансеров профессионалов стремятся переехать за границу с целью улучшения условий жизни, и работать на удаленном доступе. Некоторые государства, заинтересованные притоком квалифицированных, компетентных сотрудников, предоставляют им визы фрилансеров (например, Германия). Все вышеперечисленное и делают фриланс более привлекательным.

Возможность самостоятельно выбирать проекты для клиентов, которые интересны фрилансеру

Это возможность позволяет фрилансеру самостоятельно выбирать как проекты, так и заказчиков. Она напрямую зависит от успеха фрилансера на рынке. Это могут себе позволить фрилансеры, которые обладают определенным имиджем на рынке, и имеют ряд постоянных клиентов, что позволяет им сконцентрировать свои усилия на интересных проектах.

Независимость от формального образования и прочих качеств работника, мало связанных с его реальной эффективностью

В своих исследованиях М. Спенс [44] отмечал, чтобы устроиться на работу традиционным образом, необходимо наличие формального уровня образования. На решения руководителя при приеме на работу оказывают влияние ряд объективных и субъективных факторов (возраст, пол, внешний вид), которые не отражают профессиональных качеств сотрудника. Поэтому руководители, анализируя портфолио и отзывы о фрилансерах на специализированных биржах, получают возможность получить подходящего специалиста. Результатом механизма этой системы является то, что профессионалы, не имеющие соответствующего образования и подвергающиеся дискриминации (по полу, по возрасту, по расе), могут получить более высокую оплату и оценку своих навыков. 
Независимость доступа $\kappa$ знаниям от географического местоположения

Одно из приоритетных направлений государственной политики это проникновение высокоскоростного интернета в села (государственная программа «Цифровой Казахстан»). Реализация данной программы дала возможность периферии получить доступ к качественному образованию в режиме онлайн. Это обеспечило приток внештатных сотрудников на рынок фриланса из отдаленных регионов.

\section{Факторы индивидуального характера}

К данным факторам относятся регистрация на бирже фриланса, ведение собственного сайта, имеющийся рейтинг, наличие отзывов о работе, стаж в данной области. Наличие данных факторов способствуют развитию фрилансера и увеличению предложений со стороны заказчиков.

\section{Заключение}

Проведенное исследование позволяет резюмировать следующие выводы:

1. Рынок фриланс услуг тесно взаимодействует с ситуацией на рынке труда. Достаточно высокий уровень безработицы, отсутствие возможности устроиться по специальности вынуждают людей к самозанятости. Последствия экономического кризиса отразились в увеличении желания работодателей экономить на постоянных и трансакционных издержках. При этом перевод большинства сотрудников на удаленную работу способствовал повышению их конкурентоспособности.

2. Развитие рынка фриланс способствует развитию неперспективных регионов; фрилансеры имеют свободный график, удобные условия труда, возможность распределения и контроля своего времени и т.Д., но в то же время находятся в жесткой зависимости от колебаний рынка; отсутствие норм, регулирующих отношения между фрилансером и заказчиком, ограничивают их доступ к социальным благам и делают их социально незащищенными.

3. Описание факторов, обуславливающих рост спроса на услуги фрилансера и рост предложения на рынке фриланса, подробно раскрывают все трудности, с которыми сталкивается фрилансер (нерегулярность, ограниченный денежный поток, и трудности с обеспечением социальной защиты и т.д.), и преимущества (гибкий график, возможность самореализоваться, возможность заниматься любимым делом и т.д.).
4. Таким образом, общим фактором развития фриланса является высокая скорость развития информационно-коммуникационных технологий, которая связана с низкими предельными издержками и недорогой стоимостью продуктов ИКТ. Информатизация современной экономики привела к повышению роли творческого и интеллектуального труда. Развитие интернета позволило взаимодействовать фрилансеру и работодателю, находясь на расстоянии друг от друга, а результаты творческого интеллектуального труда исполнителя передавать через сети Интернет. Все это ускорило процесс развития рынка фриланса и дало возможность для заработка внештатным сотрудникам. На сегодняшний день удаленная работа - это обычное явление, даже крупные фирмы нанимают удаленных сотрудников.

5. Содействие активному развитию рынка фриланса в Казахстане может осуществляться в следующих направлениях:

- развитие соответствующей среды: расширение охвата населения интернетом, повышение цифровой грамотности населения и стимулирование создания фриланс-бирж;

- формирование благоприятных условий для легализации трудовой деятельности фрилансеров путем внесения поправок в соответствующие нормативно-правовые документы;

- способствовать развитию электронных платежных систем, электронной подписи и совершенствованию электронного документооборота;

- внедрить учет статистических показателей, характеризующих состояние рынка фриланса;

- проведение регулярного анкетирования фрилансеров для обеспечения базы аналитического сопровождения проектов решений по развитию фриланса в Казахстане.

В перспективе целесообразно создание полифункциональной интернет-биржи, в которой будут охвачены субъекты рынка фриланса: непосредственно сами фрилансеры или исполнители, сторона спроса, и заказчики, формирующие предложение на этом рынке. Создание полифункциональной фриланс-биржи позволит обеспечить рынок фрилансеров и заказчиков их услуг современной, удобной и востребованной цифровой платформой, а также будет выполнять функцию профсоюза, арбитра и места притяжения талантов и профессионалов, работающих самостоятельно в различных видах экономической деятельности инновационной экономики. 


\section{Список использованных источников}

1. Sharp, L., Torp, S., Van Hoof, E., de Boer, A G E M (2017). Cancer and its impact on work among the self-employed: A need to bridge the knowledge gap. European journal of cancer care, 26(5), 12-46. doi: 10.1111/ecc. 12746

2. Irmeja, A., Leibus, I. (2012). State Aid for Self-Employed Persons in Latvia and Other European Union Member States. Economic Science for Rural Development (Latvia), 28, 187-193. Edition.

3. Scott, W. (1998). Ivanhoe. Edinburgh

4. Шевчук А.В. (2008). Самозанятость в информационной экономике: основные типы и понятия. Экономическая социология, 9(1), 51-64.

5. Benson, J., Brown, M. (2007). Knowledge Workers: What Keeps Them Committed; What Turns Them away? Work, Employment \& Society, 21(1),121141. doi:10.1177/0950017007073623

6. Pink, D. (2002). Free agent nation: The future of working for yourself. NewYork, NY: Warner Books.

7. Стребков Д.О., Шевчук А.В. (2009). Фрилансеры в информационной экономике: как россияне осваивают новые формы организации труда и занятости (по результатам Первой всероссийской переписи фрилансеров). М.: Изд. дом Государственного университета - Высшей школы экономики.

8. Leighton, P., Syrett, M., Hecker, R., Holland, P. (2007). Out of the Shadows: Managing selfemployed, agency and outsourced workers. Oxford UK. Butterworth-Heinemann.

9. Burke, A., Cowling, M. (2020): The relationship between freelance workforce intensity, business performance and job creation. Small Business Economics, 55(2), 399-413. doi: 10.1007/s11187-01900241-x.

10. Zhuravlyov, V., Matrosov, A., \&Rutko, D. (2012). Behavior pattern simulation of freelance marketplace. Trends in Practical Applications of Agents and Multiagent Systems/Part of the series Advances in Intelligent and Soft Computing, 157, 157-164. https:// doi.org/10.1007/978-3-642-28795-4 19.

11. Cranford, C., Fudge, J., Tucker, E., Vosko, L. F. (2005). Self-employed workers organize: Law, policy, and unions. Montreal, QC: McGill-Queen's University Press.

12. Akhmetshin, E. M., Kovalenko, K. E., Mueller, J. E., Khakimov, A. K., Yumashev, A. V., Khairullina, A. D. (2018). Freelancing as a type of entrepreneurship: Advantages, disadvantages and development prospects. Journal of Entrepreneurship Education, 21 (S2), 1.

13. Grimov, O. (2016). Main features of freelancing as a non-standard form of employment. Economic Annals-XXI, 157(3-4), 79-81. doi: 10.21003/ ea.V157-0024.

14. Absalyamova, S. G., Absalyamov, T. B. (2015). Remote employment as a form of labor mobility of today's youth. Mediterranean Journal of Social Sciences, 6(1S3), 227-231. doi: 10.5901/mjss.2015. v6n1s3p227.
15. Афанаскина Е.М. (2015). Фрилансеры как двигатели виртуальной занятости. Горизонты экономики, 5 (24), 101-105.

16. Бычков А. (2018). Дизайн и фриланс. Начало.М.: АСТ.

17. Baitenizov, D. T., Dubina, I. N., Campbell, D.F.J., Carayannis, E. G., Azatbek, T. A. (2019). Freelance as a Creative Mode of Self-employment in a New Economy (a Literature Review). Journal of the Knowledge Economy, 10(1), 1-17. doi: 10.1007/s13132018-0574-5.

18. Merkel, J. (2018). Freelance isn't free.' Coworkingasacriticalurbanpractice tocopewithinformality in creative labour markets. Urban Studies, 56(3),526547. https://doi.org/10.1177/0042098018782374

19. Scully-Russ, E., Torraco, R. (2020). The Changing Nature and Organization of Work: An Integrative Review of the Literature. Human Resource Development Review, 19(1), 66-93. doi: $10.1177 / 1534484319886394$.

20. Heusch, S. de (2018). The blurring of employment boundaries: A social economy perspective. The Deconstruction of Employment as a Political Question: Employment' as a Floating Signifier, 179198. doi: 10.1007/978-3-319-93617-8 8

21. Remeikiene, R., Startiene, G. (2013). The structure of the model of self-employment factors in the country with transition economy: Lithuanian case. Transformations Business \& Economics, 2(29), 184196.

22. Дрокина К.В. (2021). Факторы, влияющие на развитие рынка фриланса в России. Вектор экономики, 3(57). doi: 10.51691/2500-3666_2021_3_8

23. Тагаров Б.Ж. (2018). Факторы развития рынка фриланса в информационной экономике. Креативная экономика, 12(10), 1703-1713. doi:10.18334/ce.12.10.39450

24. Полетаева О.В. (2017). Социальные факторы появления фрилансеров в структуре занятого населения. Общественные науки. Социология, 1(41), 119-129. doi:10.21685/2072-30162017-1-12

25. Stephany, F., Dunn, M., Sawyer, S., Lehdonvirta, V. (2020). Distancing Bonus Or Downscaling Loss? The Changing Livelihood of Us Online Workers in Times of COVID-19. Tijdschrift voor Economischeen Sociale Geografie, 111(3), 561-573. doi:10.1111/tesg.12455.

26. Рынок фриланса: цифры, деньги, влияние пандемии и тренды 2021. Блог Kwork; 2021 [обновлено 30 мая 2021; процитировано 10 июля 2021]. Доступно: https://blog.kwork.ru/rynokfrilansa/rynok-frilansa-cifry-dengi-vliyanie-pandemiii-trendy-2021

27. Колесникова Т.В., Перчинская Н. П. (2014). Фриланс - нестандартная форма занятости, инновационная тенденция на современном рынке труда. Инновации, 5(187), 42-46.

28. Чечулина М.Ю. (2016). Фриланс как развивающаяся форма модернизации экономической активности. Экономика труда, 3 (3), 291-306.

29. Киреева А.А., Урдабаев, М.Т., Ермекбаева, Д.Д. (2020). Оценка уровня развития ИКТ в регионах Казахстана в условиях перехода к 
Индустрии 4.0. Экономика: стратегия и практика, 3 (15), 62-75.

30. Сергеева Ю. Вся статистика интернета на 2020 год - цифры и тренды в мире и в России. WebCanape; 2021 [обновлено 10 февраля 2021; процитировано 12 июля 2021]. Доступно: https:// www.web-canape.ru/business/internet-2020globalnaya-statistika-i-trendy/

31. Цифровая грамотность населения: какие регионы в антилидерах? Центр деловой информации Капитал; 2021 [обновлено 30 апреля 2021; процитировано 12 июля 2021]. Доступно: https:// kapital.kz/tehnology/95314/tsifrovaya-gramotnostnaseleniya-kakiye-regiony-v-antiliderakh.html

32. Сапожникова М. Свобода по выбору: настоящее и будущее фриланса в России. РБК Тренды; 2021 [обновлено 17 июня 2021; процитировано 16 июля 2021]. Доступно: https:// trends.rbc.ru/trends/social/60c8e3139a79472ba64fde35

33. Сорокина М.В. (2017). Менеджмент в торговле. СПб.: Питер.

34. Бурлуцкая М. Г., Харченко В.С. (2016). Фрилансеры: специфика социального статуса, стратегии карьеры и профессионального развития. Социология и социальная антропология, 16 (1), 111 123.

35. Харченко В.С. (2014). Образ жизни российских фрилансеров: социологический анализ. Социологические исследования, 5, 54-63.

36. Смит А. (1993). Исследование о природе и причинах богатства народов. М.: Наука.

37. Казарина Л.А. (2018). Аутсорсинг функций как инструмент повышения конкурентоспособности фирмы. Baikal Research Journal, 9(1). doi:10.17150/2411-6262.2018.9(1).9.

38. Платформенный подход к труду. Партнерский проект Коммерсантъ; 2021 [процитировано 15 июля 2021]. Доступно: https:// special.kommersant.ru/pandemic/rocket-2.html

39. Рынок фриланса 2020: спрос на тексты и дизайн, рост среднего заработка несмотря на пандемию. Kwork; 2020 [обновлено 29 декабря 2020; процитировано 25 июля 2021]. Доступно: https://vc.ru/kwork/192015-rynok-frilansa-2020-sprosna-teksty-i-dizayn-rost-srednego-zarabotka-nesmotryana-pandemiyu

40. Сонный С. Раскрыт доход фрилансеров в России. Газета.ru; 2021 [обновлено 16 февраля 2021; процитировано 12 июля 2021]. Доступно: https://www. gazeta.ru/business/news/2021/02/16/n_15626954.shtml

41. Курманбеков А. Рынок труда Казахстана - сдержанный рост. Halykfinance; 2019 [обновлено 11 октября 2019; процитировано 12 июля 2021]. Доступно: https://halykfinance.kz/download/ files/company-documents/research/labour2019.pdf

42. Фриланс: что это такое и как HR-y работать с фрилансерами. Hurma; 2020 [обновлено 24 июля 2020; процитировано 15 июля 2021]. Доступно: https://hurma.work/ru/blog/frilans-chto-etotakoe-i-kak-hr-u-rabotat-s-frilanserami/

43. Кох Р. (2012). Принцип 80/20 [пер. с англ.].М., Эксмо.
44. Spence, M. (2010). Job market signaling. Quarterly Journal of Economics, 3, 355-374. doi: 10.2307/1882010.

\section{References}

1. Sharp, L., Torp, S., Van Hoof, E., de Boer, A G E M (2017). Cancer and its impact on work among the self-employed: A need to bridge the knowledge gap. European journal of cancer care, 26(5): 12-46. (in Eng.)

2. Irmeja, A., Leibus, I. (2012). State Aid for Self-Employed Persons in Latvia and Other European Union Member States. Economic Science for Rural Development (Latvia), 28: 187-193. (in Eng.)

3. Scott, W. (1998). Ivanhoe. Edinburgh Edition. pp: 21. (in Eng.)

4. Shevchuk, A.V. (2008). [Self-employment in the information economy: basic types and concepts.] Самозанятость в информационной экономике: основные типы и понятия. Economic sociology, 9(1), 51-64. (in Russ.)

5. Benson , J., Brown, M. (2007). Knowledge Workers: What Keeps Them Committed; What Turns Them away? Work, Employment \& Society, 21(1): 121141. (in Eng.)

6. Pink, D. (2002). Free agent nation: The future of working for yourself. NewYork, NY: Warner Books. pp: 400. (in Eng.)

7. Strebkov, D.O., Shevchuk, A.V. (2009). [Freelancers in the information economy: how russians master new forms of labor and employment organization (based on the results of the First all-russian census of freelancers)] Frilansery $v$ informatsionnoi ehkonomike: kak rossiyane osvaivayut novye formy organizatsii truda $i$ zanyatosti (po rezul'tatam Pervoi vserossiiskoi perepisi frilanserov). M.: Izd. dom Gosudarstvennogo universiteta - Vysshei shkoly ehkonomiki, 70 p. (in Russ.)

8. Leighton, P., Syrett, M., Hecker, R., Holland, P. (2007). Out of the Shadows: Managing selfemployed, agency and outsourced workers. Oxford UK. Butterworth-Heinemann. pp: 289. (in Eng.)

9. Burke, A., Cowling, M. (2020): The relationship between freelance workforce intensity, business performance and job creation. Small Business Economics, 55(2): 399-413. (in Eng.)

10. Zhuravlyov, V., Matrosov, A., \&Rutko, D. (2012). Behavior pattern simulation of freelance marketplace. Trends in Practical Applications of Agents and Multiagent Systems/Part of the series Advances in Intelligent and Soft Computing, 157: 157-164. (in Eng.)

11. Cranford, C., Fudge, J., Tucker, E., Vosko, L. F. (2005). Self-employed workers organize: Law, policy, and unions. Montreal, QC: McGill-Queen's University Press. pp: 138. (in Eng.)

12. Akhmetshin, E. M., Kovalenko, K. E., Mueller, J. E., Khakimov, A. K., Yumashev, A. V., Khairullina, A. D. (2018). Freelancing as a type of entrepreneurship: Advantages, disadvantages and development prospects. Journal of Entrepreneurship Education, 21 (S2): 1. (in Eng.) 
13. Grimov, O. (2016). Main features of freelancing as a non-standard form of employment. Economic Annals-XXI, 157(3-4): 79-81. (in Eng.)

14. Absalyamova, S.G., Absalyamov, T.B. (2015). Remote employment as a form of labor mobility of today's youth. Mediterranean Journal of Social Sciences, 6(1S3): 227-231. (in Eng.)

15. Afanaskina, E.M. (2015). [Freelancers as engines of virtual employment.] Фрилансеры как двигатели виртуальной занятости. Economic horizons, 5 (24), 101-105. (in Russ.)

16. Bychkov, A. (2018). [Design and freelance] Dizain i frilans. Nachalo.M.: AST, 208 p. (in Russ.)

17. Baitenizov, D.T., Dubina, I.N., Campbell, D.F.J., Carayannis, E.G., Azatbek, T.A. (2019). Freelance as a Creative Mode of Self-employment in a New Economy (a Literature Review). Journal of the Knowledge Economy, 10 (1): 1-17. (in Eng.)

18. Merkel, J. (2018). Freelance isn't free.' Co-working as a critical urban practice to cope with informality in creative labour markets. Urban Studies, 56(3): 526-547. (in Eng.)

19. Scully-Russ, E., Torraco, R. (2020). The Changing Nature and Organization of Work: An Integrative Review of the Literature. Human Resource Development Review, 19(1): 66-93. (in Eng.)

20. Heusch, S. de (2018). The blurring of employment boundaries: A social economy perspective. The Deconstruction of Employment as a Political Question: Employment' as a Floating Signifier, 179198. (in Eng.)

21. Remeikiene, R., Startiene, G. (2013). The structure of the model of self-employment factors in the country with transition economy: Lithuanian case. Transformations Business \& Economics, 2(29): 184196. (in Eng.)

22. Drokina, K.V. (2021). [Factors influencing the development of the freelance market in Russia.] Факторы, влияющие на развитие рынка фриланса в России. Economy vector, 3(57). (in Russ.)

23. Tagarov, B.ZH. (2018). [Freelance market development factors in the information economy.] Факторы развития рынка фриланса в информационной экономике. Creative economy, 12(10), 1703-1713. (in Russ.)

24. Poletaeva, O.V. (2017). [Social factors of the emergence of freelancers in the structure of the employed population.] Социальные факторы появления фрилансеров в структуре занятого населения. Social sciences. Sociology, 1(41), 119-129. (in Russ.)

25. Stephany, F., Dunn, M., Sawyer, S., Lehdonvirta, V. (2020). Distancing Bonus Or Downscaling Loss? The Changing Livelihood of Us Online Workers in Times of COVID-19. Tijdschrift voor Economische en Sociale Geografie, 111(3): 561-573. (in Eng.)

26. [Freelance market: numbers, money, impact of the pandemic and trends in 2021] Rynok frilansa: tsifry, den'gi, vliyanie pandemii i trendy 2021 [URL: https://blog.kwork.ru/rynok-frilansa/rynok-frilansacifry-dengi-vliyanie-pandemii-i-trendy-2021].Blog. Kwork, 2021 [updated May 30, 2021; cited 10 Jul 2021]. (in Russ.)
27. Kolesnikova, T.V., Perchinskaya N. P. (2014). [Freelancing is a non-standard form of employment, an innovative trend in the modern labor market.] Фриланс - нестандартная форма занятости, инновационная тенденция на современном рынке труда. Innovations, 5(187), 42-46. (in Russ.)

28. Chechulina, M.YU. (2016). [Freelance as a developing form of modernization of economic activity.] Фриланс как развивающаяся форма модернизации экономической активности. Labor economic, 3 (3), 291-306. (in Russ.)

29. Kireeva, A.A., Urdabaev, M.T., Ermekbaeva, D.D. (2020). [Assessment of the level of ICT development in the regions of Kazakhstan in the context of the transition to Industry 4.0.] Оценка уровня развития ИКТ в регионах Казахстана в условиях перехода к Индустрии 4.0. Economics: strategy and practice, 3 (15), 62-75. (in Russ.)

30. Sergeeva, YU. [All internet statistics for 2020 - numbers and trends in the world and in Russia] Vsya statistika interneta na 2020 god - tsifry i trendy v mire i v Rossii [URL: https://www.web-canape.ru/ business/internet-2020-globalnaya-statistika-i-trendy/]. WebCanape, 2021 [updated 10 Feb 2021; cited 2021 Jul 12]. (in Russ.)

31. [Digital literacy of the population: which regions are among the anti-leaders?] Tsifrovaya gramotnost' naseleniya: kakie regiony $\mathrm{v}$ antiliderakh? [URL:https://kapital.kz/tehnology/95314/tsifrovayagramotnost-naseleniya-kakiye-regiony-v-antiliderakh. html]. Business Information Center Capital, 2021 [updated April 30, 2021; cited 2021 Jul 12]. (in Russ.)

32. Sapozhnikova, M. [Freedom of choice: the present and future of freelancing in Russia] Svoboda po vyboru: nastoyashchee $\mathrm{i}$ budushchee frilansa $\mathrm{V}$ Rossii[URL:https://trends.rbc.ru/trends/social/60c8e31 39a79472ba64fde35]. RBK Trends, 2021 [updated June 17, 2021; cited 2021 Jul 16]. (in Russ.)

33. Sorokina, M.V. (2017). [Trade management] Menedzhment v torgovle. SPb.: Piter,752 p. (in Russ.)

34. Burlutskaya, M. G., Kharchenko, V.S. (2016). [Freelancers: specifics of social status, career strategies and professional development.] Фрилансеры: специфика социального статуса, стратегии карьеры и профессионального развития. Sociology and social anthropology, 16(1), 111-123. (in Russ.)

35. Kharchenko, V.S. (2014). [The way of life of russian freelancers: a sociological analysis.] Образ жизни российских фрилансеров: социологический анализ. Sociological research, 5, 54-63. (in Russ.)

36. Smit, A. (1993). [Research on the nature and causes of the wealth of nations] Issledovanie o prirode i prichinakh bogatstva narodov. M.: Nauka. 570 p. (in Russ.)

37. Kazarina, L.A. (2018). [Outsourcing of functions as a tool to improve the competitiveness of a company.] Аутсорсинг функций как инструмент повышения конкурентоспособности фирмы. Baikal Research Journal, 9(1). (in Russ.)

38. [Platform approach to work] Platformennyi podkhod k trudu [URL: https://special.kommersant.ru/ pandemic/rocket-2.html]. Kommersantpartnerproject, 2021 [cited 20 Jul 15, 2021]. (in Russ.) 
39. [Freelance market 2020: demand for texts and design, growth in average earnings despite the pandemic] Rynok frilansa 2020: spros na teksty i dizain, rost srednego zarabotka nesmotrya na pandemiyu [URL: https://vc.ru/kwork/192015-rynok-frilansa-2020-sprosna-teksty-i-dizayn-rost-srednego-zarabotka-nesmotryana-pandemiyu]. Kwork, 2020 [updated December 29, 2020; cited 2021 Jul 25]. (in Russ.)

40. Sonnyi, S. [Income of freelancers in Russia disclosed] Raskryt dokhod frilanserov $\mathrm{V}$ Rossii [URL: https:/www.gazeta.ru/business/ news/2021/02/16/n_15626954.shtml]. Gazeta.ru, 2021 [updated February 16, 2021; cited 2021 Jul 12]. (in Russ.)
41. Kurmanbekov, A. [Labor market in Kazakhstan - moderate growth] Rynok truda Kazakhstana - sderzhannyi rost [URL: https:// halykfinance.kz/download/files/company-documents/ research/labour2019.pdf]. Halykfinance, 2019 [updated October 11, 2019; cited 2021 Jul 12]. (in Russ.)

42. [Freelance: what is it and how does HR work with freelancers] Frilans: chto ehto takoe i kak HR-u rabotat' s frilanserami [URL: https://hurma. work/ru/blog/frilans-chto-eto-takoe-i-kak-hr-u-rabotats-frilanserami/]. Hurma, 2020 [updated July 24, 2020; cited 2021 Jul 15]. (in Russ.)

43. Kokh, R. (2012). [The 80/20 principle [trans. from English] Printsip 80/20 [per. s angl.]. M., Ehksmo, 340p. (in Russ.)

44. Spence, M. (2010). Job market signaling. Quarterly Journal of Economics, 3: 355-374. (in Eng.)

\section{Information about the authors}

* Diana Zh. Abdreissova- 2nd year doctoral student of the specialty «Economics», M.Kozybaev North Kazakhstan
University, Kazakhstan, e-mail: diana_gmu05@mail.ru; ORCID ID: https://orcid.org/0000-0003-1007-8007.

Daniyar T. Baitenizov - PhD, Associate Professor of the Department of Economics and Accounting, M. Kozybaev North Kazakhstan University; Kazakhstan, e-mail: baitenizov84@mail.ru; Scopus Author ID: 57208010069; ORCID ID: https://orcid.org/0000-0001-9610-3722.

Tolkyn A. Azatbek - Doctor of Economics, Professor of the Department of Economics and Entrepreneurship, L.N. Gumilyov Eurasian National University, Kazakhstan, e-mail: tolkyn_d2005@mail.ru; Scopus Author ID: 55536728100; ORCID ID: https://orcid.org/0000-0003-0750-8811.

Saltanat N. Valieva - PhD, Senior lecturer of the Department of Management, Kazakh University of Economics, Finance and International Trade, Kazakhstan, e-mail: saltanat.valieva.75@mail.ru; ORCID ID: https://orcid.org/00000003-2837-4066.

\section{Авторлар туралы ақпарат}

* Абдреисова Д.Ж. - «Экономика» мамандығының 2 курс докторанты, М. Қозыбаев атындағы Солтүстік Қазақстан университеті, Қазақстан, e-mail: diana_gmu05@mail.ru; ORCID ID: https://orcid.org/00000003-1007-8007.

Байтенизов Д.Т. - PhD, М.Қозыбаев атындағы Солтүстік Қазақстан университетінің«Экономика және есеп» кафедрасының доценті, Қазақстан, e-mail: baitenizov84@mail.ru; Scopus Author ID: 57208010069; ORCID ID: https://orcid.org/0000-0001-9610-3722.

Азатбек Т.А. - экономика ғылымдарының докторы, Л.Н. Гумилев атындағы Еуразия ұлттық университетінің «Экономика және кәсіпкерлік» кафедрасының профессоры, Қазақстан, е-таil: tolkyn_d2005@mail.ru; Scopus Author ID: 55536728100; ORCID ID: https://orcid.org/0000-0003-0750-8811.

Валиева С.H. - PhD, Қазақ экономика, қаржы және халықаралық сауда университетінің «Менеджмент» кафедрасының оқытушысы, Қазақстан, e-mail: saltanat.valieva.75@mail.ru; ORCID ID: https://orcid.org/00000003-2837-4066. 


\section{Информация об авторах:}

* Абдреисова Д.Ж. - докторант 2 курса специальности «Экономика», Северо-Казахстанский университет им. М.Козыбаева, Казахстан, e-mail: diana_gmu05@mail.ru; ORCID ID:https://orcid.org/0000-0003-1007-8007.

Байтенизов Д.Т. - $\mathrm{PhD}$, доцент кафедры «Экономика и учет» Северо-Казахстанского университета им.М.Козыбаева; Казахстан, e-mail: baitenizov84@mail.ru; ScopusAuthorID: 57208010069; ORCID ID: https:// orcid.org/0000-0001-9610-3722.

Азатбек Т.А. - доктор экономических наук, профессор кафедры «Экономика и предпринимательство» Евразийского национального университета им. Л.Н. Гумилева, Казахстан, e-mail: tolkyn_d2005@mail.ru; Scopus Author ID: 55536728100; ORCID ID:https://orcid.org/0000-0003-0750-8811.

Валиева С.H. - PhD, ст. преподаватель кафедры «Менеджмент» Казахского университета экономики, финансов и международной торговли, Казахстан, е-mail: saltanat.valieva.75@mail.ru; ORCID ID: https://orcid. org/0000-0003-2837-4066. 